\title{
Cloning, expression and characterization of a cold-adapted endo-1, 4- $\beta$-glucanase from Citrobacter farmeri A1, a symbiotic bacterium of Reticulitermes labralis
}

\author{
Xi Bai ${ }^{1}$, Xianjun Yuan ${ }^{1}$, Aiyou Wen ${ }^{2}$, Junfeng Li ${ }^{1}$, Yunfeng Bai ${ }^{3}$, Tao Shao ${ }^{\text {Corresp. } 1}$ \\ 1 Institute of Ensiling and Processing of Grass, Nanjing Agricultural University, Nanjing, China \\ 2 College of Animal Science, University of Science and Technology of Anhui, Fengyang, China \\ 3 Institute of Agricultural Resource and Environment, Jiangsu Academy of Agricultural Sciences, Nanjing, China \\ Corresponding Author: Tao Shao \\ Email address: taoshaolan@163.com
}

Background. Many biotechnological and industrial applications can benefit from coldadapted EgICs through increased efficiency of catalytic processes at low temperature. In our previous study, Citrobacter farmeri Al which was isolated from a wood-inhabiting termite Reticulitermes labralis could secrete a cold-adapted EgIC. However, its EgIC was difficult to purify for enzymatic properties detection because of its low activity $(0.8 \mathrm{U} / \mathrm{ml})$. The objective of the present study was to clone and express the $C$. farmeri EgIC gene in Escherichia coli to improve production level and determine the enzymatic properties of the recombinant enzyme. Methods. The EgIC gene was cloned from $C$. farmeri A1 by thermal asymmetric interlaced PCR. EgIC was transformed into vector $\mathrm{pET} 22 \mathrm{~b}$ and functionally expressed in E. coli. The recombination protein EgIC22b was purified for properties detection. Results. SDS-PAGE revealed that the molecular mass of the recombinant endoglucanase was approximately $42 \mathrm{kDa}$. The activity of the $E$. coli $\mathrm{pET} 22 \mathrm{~b}$-EgIC crude extract was $9.5 \mathrm{U} / \mathrm{ml}$. Additionally, it was active at $\mathrm{pH}$ 6.5-8.0 with an optimum $\mathrm{pH}$ of 7.0. The recombinant enzyme had an optimal temperature of $30-40{ }^{\circ} \mathrm{C}$ and exhibited $>50 \%$ relative activity even at $5{ }^{\circ} \mathrm{C}$, whereas it lost approximately $90 \%$ of its activity after incubation at $60{ }^{\circ} \mathrm{C}$ for 30 min. Its activity was enhanced by $\mathrm{Co}^{2+}$ and $\mathrm{Fe}^{3+}$, but inhibited by $\mathrm{Cd}^{2+}, \mathrm{Zn}^{2+}, \mathrm{Li}^{+}$, Triton X-100, DMSO, acetonitrile, Tween 80, SDS, and EDTA. Conclusion. These biochemical properties indicate that the recombinant enzyme is a cold-adapted endoglucanase that can be used for various industrial applications. 
1 Cloning, expression and characterization of a cold-adapted endo-1, 4- $\beta$ -

2 glucanase from Citrobacter farmeri A1, a symbiotic bacterium of

3 Reticulitermes labralis

4 Xi Bai ${ }^{1}$, Xianjun Yuan ${ }^{1}$, Aiyou Wen ${ }^{2}$, Junfeng $\mathrm{Li}^{1}$, Yunfeng Bai ${ }^{3}$, Tao Shao ${ }^{1 *}$

$5 \quad{ }^{1}$ Institute of Ensiling and Processing of Grass, Nanjing Agricultural University, Nanjing, China

$6 \quad{ }^{2}$ College of Animal Sciences and Technology, University of Science and Technology of Anhui,

7 Fengyang, China

$8 \quad{ }^{3}$ Institute of Agricultural Resource and Environment, Jiangsu Academy of Agricultural Sciences,

9 Nanjing, China

10

$12{ }^{*}$ Corresponding author

Dr. Tao Shao

Institute of Ensiling and Processing of Grass, Nanjing Agricultural University, Nanjing, China

Tel: 86-025-84396130; Fax: 86-025-84396130

E-mail: taoshaolan@163.com (TS) 


\section{Abstract}

Background. Many biotechnological and industrial applications can benefit from cold-adapted EglCs through increased efficiency of catalytic processes at low temperature. In our previous study, Citrobacter farmeri A1 which was isolated from a wood-inhabiting termite Reticulitermes labralis could secrete a cold-adapted EglC. However, its EglC was difficult to purify for enzymatic properties detection because of its low activity $(0.8 \mathrm{U} / \mathrm{ml})$. The objective of the present study was to clone and express the C. farmeri EglC gene in Escherichia coli to improve production level and determine the enzymatic properties of the recombinant enzyme.

Methods. The $E g l C$ gene was cloned from $C$. farmeri A1 by thermal asymmetric interlaced PCR. EglC was transformed into vector pET22b and functionally expressed in E. coli. The recombination protein EglC22b was purified for properties detection.

Results. SDS-PAGE revealed that the molecular mass of the recombinant endoglucanase was approximately $42 \mathrm{kDa}$. The activity of the $E$. coli pET22b-EglC crude extract was $9.5 \mathrm{U} / \mathrm{ml}$. Additionally, it was active at $\mathrm{pH}$ 6.5-8.0 with an optimum $\mathrm{pH}$ of 7.0. The recombinant enzyme had an optimal temperature of $30-40{ }^{\circ} \mathrm{C}$ and exhibited $>50 \%$ relative activity even at $5{ }^{\circ} \mathrm{C}$, whereas it lost approximately $90 \%$ of its activity after incubation at $60{ }^{\circ} \mathrm{C}$ for $30 \mathrm{~min}$. Its activity was enhanced by $\mathrm{Co}^{2+}$ and $\mathrm{Fe}^{3+}$, but inhibited by $\mathrm{Cd}^{2+}, \mathrm{Zn}^{2+}, \mathrm{Li}^{+}$, Triton $\mathrm{X}-100, \mathrm{DMSO}$, acetonitrile, Tween 80, SDS, and EDTA.

Conclusion. These biochemical properties indicate that the recombinant enzyme is a coldadapted endoglucanase that can be used for various industrial applications. 

cellulose into sugars (Ogura et al., 2006; Limayem et al. 2012; Shelomi et al., 2014). The complete degradation of cellulose requires three different cellulases: endo-1,4- $\beta$-glucanase, exo1,4- $\beta$-glucanase, and 1,4- $\beta$-glucosidase (Ozioko et al., 2013). Endo- $\beta$-1,4-glucanase (EglC, EC 3.2.1.4) is an important enzyme that hydrolyzes glycosidic linkages and releases oligosaccharides of different lengths. Some studies have suggested that EglC is more effective than exoglucanase and glucosidase for degrading cellulose (Yasir et al., 2013).

Numerous biotechnological and industrial applications can benefit from cold-adapted EglCs through increased efficiency of catalytic processes at low temperature (Kasana and Gulati, 2011). However, cold-adapted EglCs are generally not thermally stability and can easily be inactivated by elevated temperatures (Vester et al., 2014). Such processes have the merits of saving production and energy costs, maintaining taste and other organoleptic characteristics, and reducing the risk of contamination (Vester et al., 2014).

For application in the biofuel industry, cold-adapted EglCs can produce ethanol from cellulosic material at low temperature (Cavicchioli et al., 2011). However, the biological conversion of cellulose to bioethanol is typically performed at relatively high temperatures (50$60^{\circ} \mathrm{C}$ ), which can increase energy consumption and production costs (Cavicchioli et al., 2011; Tiwari et al. 2015). Cold-adapted EglCs can also be used in the degradation of polymer in pulp and paper processes, stonewashing and bio-polishing of textiles, and in the food, silage and feed industries (Kasana and Gulati, 2011). Based on these applications, cold-adapted EglCs have 
attracted increased attention (Maharana et al., 2015; Gerday et al., 2000). However, few coldadapted $\beta$-glucanases have been identified and cloned to date (Bhat et al., 2013; Cavicchioli et al., 2011).

EglC genes from some microorganisms have been cloned and expressed in Escherichia coli for secretion of endoglucanases (Kasana et al., 2011). Termites have a rich variety of commensal microbes in their intestinal tracts that efficiently digest lignocellulose, and are thus considered as promising reservoirs of microbial symbionts and enzymes with high biotechnological potential (Brune, 2014). In our previous study, Citrobacter farmeri A1 that secreted cold-adapted EglC was isolated from the wood-inhabiting termite Reticulitermes labralis (unpublished). However, the activity of this EglC was low $(0.8 \mathrm{U} / \mathrm{ml})$. The objective of the present work was to clone and express the $\mathrm{EglC}$ gene of $C$. farmeri to improve production level and determine the enzymatic properties of the recombinant enzyme.

\section{MATERIALS AND METHODS}

\section{Plasmids, chemicals, and culture medium}

C. farmeri A1 that secreted cold-adapted EglC was isolated from R. labralis and stored in our laboratory. The plasmid pMD20-T vector (TaKaRa, Dalian, China) and E. coli DH5 $\alpha$ were used for gene cloning, whereas the pET22b vector (Novagen, Madison, WI) and E. coli BL21 (laboratory stock) were used for gene expression. The flanking regions of the $\mathrm{EglC}$ gene were amplified using the TaKaRa Genome Walking Kit (TaKaRa, Dalian, China). Restriction endonucleases, T4 DNA ligase, and DNA polymerase were purchased from TaKaRa (Dalian, China). TIANgel Midi Purification Kit, TIANprep Mini Plasmid Kit, and $2 \times$ Taq PCR Master Mix were purchased from Tiangen (Beijing, China).

\section{EglC gene cloning}


91

92

93

94

95

96

Genomic DNA of $C$. farmeri A1 was isolated using the TIANamp Bacteria DNA Kit (Tiangen, Beijing, China). The core region of the $E g l C$ gene was amplified using the degenerate primers GH8-F and GH8-R (Table 1), which were designed based on two conserved blocks, EGQSY[A/G][M/L]FFAL and DAIRVY[L/M]WAG[M/L], of the glycoside hydrolase family 8 (GH8) bacterial endoglucanases. Touchdown PCR conditions were as follows: an initial denaturation step of $5 \mathrm{~min}$ at $95{ }^{\circ} \mathrm{C}$ and 15 cycles of $30 \mathrm{~s}$ at $94{ }^{\circ} \mathrm{C}, 30 \mathrm{~s}$ at $70{ }^{\circ} \mathrm{C}$, and $20 \mathrm{~s}$ at 72 ${ }^{\circ} \mathrm{C}$, followed by 30 cycles of $30 \mathrm{~s}$ at $94{ }^{\circ} \mathrm{C}, 30 \mathrm{~s}$ at $55{ }^{\circ} \mathrm{C}$, and $40 \mathrm{~s}$ at $72{ }^{\circ} \mathrm{C}$, and a final elongation step of $10 \mathrm{~min}$ at $72{ }^{\circ} \mathrm{C}$. Amplified DNAs of the appropriate size were purified and ligated into the pMD20-T vector, and confirmed by DNA sequencing (Genscript Corporation, Nanjing, China).

Full-length EglC was amplified by thermal asymmetric interlaced PCR (TAIL-PCR) using nested insertion-specific primers designed based on the conserved domain. The 5'-flanking genomic sequences were amplified using FP-specific primers (FSP1, FSP2, and FSP3; Table 1) and the random degenerate primer $\mathrm{C} 1$, whereas the 3 '-flanking genomic sequences were amplified with RP-specific primers (RSP1, RSP2, and RSP3; Table 1) and the random degenerate primer C2 using the TaKaRa Genome Walking Kit (TaKaRa, Dalian, China). The TAIL-PCR products were ligated into the pMD20-T vector and transformed into E. coli DH5 $\alpha$ for DNA sequencing. Then, the 5'- and 3'-flanking regions were assembled with the core sequence.

Based on the assembled sequence, the GHF and GHR primers (Table 1) were used to amplify the full length of the $E g l C$ gene. The PCR program included an initial step of 6 min at $95{ }^{\circ} \mathrm{C}$, a second step of 35 cycles including $35 \mathrm{~s}$ at $95^{\circ} \mathrm{C}, 1 \mathrm{~min}$ at $60{ }^{\circ} \mathrm{C}$ and $1 \mathrm{~min}$ at $72{ }^{\circ} \mathrm{C}$, and a final 
113 step of 8 min at $72{ }^{\circ} \mathrm{C}$. The DNA product was cloned into the pMD20-T vector using standard

114 procedures and sequenced by Genscript Corporation (China).

115 Construction and transformation of the recombinant expression vectors

116 For expression of $\mathrm{EglC}$ in $\mathrm{E}$. coli, the mature protein-coding sequences (signal peptide 117 excluded) were amplified by PCR from genomic DNA of $C$. farmeri A1. The PCR primers were 118 EglC-F and EglC-R containing NcoI and XhoI sites (Table 1). The PCR program included an 119 initial step of 6 min at $95{ }^{\circ} \mathrm{C}$, a second step of 35 cycles including $35 \mathrm{~s}$ at $95{ }^{\circ} \mathrm{C}, 1 \mathrm{~min}$ at $58^{\circ} \mathrm{C}$ 120 and $1 \mathrm{~min}$ at $72{ }^{\circ} \mathrm{C}$, and a final step of $8 \mathrm{~min}$ at $72{ }^{\circ} \mathrm{C}$. The purified PCR products were ligated into the pMD20-T plasmid. The vector pMD20-EglC was digested with NcoI and XhoI, and then the purified EglC gene was cloned to the pET22b vector. The resulting plasmid, pET22b-EglC, was transformed into $E$. coli BL21 and plated on LB agar containing $100 \mu \mathrm{g} \cdot \mathrm{ml}^{-1}$ ampicillin to select positive transformants. The positive clones were checked by colony PCR using EglC-F and EglC-R primers (Table 1). The plasmid pET22b-EglC was sequenced by Genscript Corporation (China).

\section{Expression of the $E g l C$ gene in $E$. coli and purification of the recombinant protein}

The recombinant E. coli pET22b-EglC was cultured at $37^{\circ} \mathrm{C}$ in LB medium with ampicillin. When the culture density reached an optical density of approximately 0.5 at $600 \mathrm{~nm}$, isopropyl-bD-1-thiogalactopyranoside (IPTG) was added into the medium to a final concentration of $1 \mathrm{mM}$ to induce endoglucanase expression. After $4 \mathrm{~h}$, cultured cells were collected by centrifugation at $10,000 \times g$ for 6 min at $4{ }^{\circ} \mathrm{C}$, resuspended in ice-cold buffer $\left(\mathrm{Na}_{2} \mathrm{HPO}_{4}\right.$-citric acid; $\left.\mathrm{pH} 7\right)$, and disrupted by sonication. Proteins were obtained by centrifugation and purified using a $\mathrm{Ni}^{2+}$ affinity chromatography column (CWBIO, China). Expressed proteins were detected by sodium 
135 dodecyl sulfate-polyacrylamide gel electrophoresis (SDS-PAGE), and their concentration was

136 determined using a Micro BCA protein assay kit (Jiancheng, Nanjing, China).

137 Detection of enzymatic activities

138 The activity of Eglc22b was determined using the 3,5-dinitrosalicylic (DNS) method as

139

140

141

142

143

144

145

146

147

148

149

150

151

152

153

154

155

156

described by Fu et al. (Fu et al., 2010). Sodium-carboxymethyl cellulose (CMC-Na) was used as a substrate at a concentration of $1.0 \%(\mathrm{w} / \mathrm{v})$. The standard reaction mixture, containing $1 \mathrm{ml}$ of appropriately diluted enzyme and $1 \mathrm{ml}$ of $\mathrm{CMC}-\mathrm{Na}$ buffer $(\mathrm{pH} 7)$, was incubated at $40{ }^{\circ} \mathrm{C}$ for 30 min. The reaction was terminated by addition of $3 \mathrm{ml}$ of DNS to the mixture and $5 \mathrm{~min}$ of boiling. The release of reducing sugars was measured at $540 \mathrm{~nm}$ by using a spectrophotometer (Shanghai Precision \& Scientific Instrument Co., Shanghai, China). One glucanase unit was defined as the amount of enzyme required to release $1 \mu \mathrm{mol}$ of glucose per minute at the assay temperature.

\section{Biochemical characteristics of EglC22b}

The optimum $\mathrm{pH}$ for the activity of EglC22b was determined at $40{ }^{\circ} \mathrm{C}$ for 30 min in $\mathrm{Na}_{2} \mathrm{HPO}_{4}$ citric acid buffer ( $\mathrm{pH}$ 3.5-7) and sodium phosphate buffer ( $\mathrm{pH}$ 8.0). To determine the $\mathrm{pH}$ stability, EglC $22 \mathrm{~b}$ was incubated at $40^{\circ} \mathrm{C}$ for $30 \mathrm{~min}$ in different buffers of $\mathrm{pH} 2.5$ to 6.5 (1.0 interval), and the residual enzyme activity was measured at optimal $\mathrm{pH}$ and temperature using the DNS method as described previously.

The optimal temperature for the activity of EglC22b was determined in $\mathrm{Na}_{2} \mathrm{HPO}_{4}$-citric acid buffer $(\mathrm{pH} 7.0)$ at $10{ }^{\circ} \mathrm{C}$ to $70{ }^{\circ} \mathrm{C}\left(10^{\circ} \mathrm{C}\right.$ interval $)$ for $30 \mathrm{~min}$. To determine the thermal stability, EglC22b was incubated at $20,30,40,50$, and $60^{\circ} \mathrm{C}$ for $30 \mathrm{~min}$ each, and the residual enzyme activity was measured at optimal $\mathrm{pH}$ and temperature using the DNS method as described previously. 
157

158

159

160

161

162

163

164

165

166

167

168

169

170

171

172

173

174

175

176

177

178

179

The effects of different metal ions and chemical reagents on the activity of EglC22b were assessed by incubating the enzyme at $40^{\circ} \mathrm{C}$ for $30 \mathrm{~min}$ in a standard reaction mixture of $\mathrm{Na}_{2} \mathrm{HPO}_{4}$-citric acid buffer ( $\mathrm{pH} 7.0$ ) containing $2 \mathrm{mmol} \cdot \mathrm{L}^{-1} \mathrm{CoCl}_{2}, \mathrm{CdCl}_{2}, \mathrm{ZnCl}_{2}, \mathrm{FeCl}_{3}, \mathrm{Li}_{2} \mathrm{SO}_{4}$, Triton X-100, dimethyl sulfoxide (DMSO), acetonitrile, Tween 80, SDS, and ethylene-diaminetetraacetic acid (EDTA). An assay system without the added metal ions was used as a control, and the enzyme activity was measured using the DNS method as described previously.

\section{Statistical analysis}

All measurements of the present study were carried out in duplicate. Data were analyzed by Microsoft Excel 2010. Data were presented as means with standard deviation (SD).

\section{RESULTS}

\section{Cloning and sequencing of $\mathrm{EglC}$}

An approximately 600-bp core region of $E g l C$ was amplified by touchdown PCR from $C$. farmeri A1. Based on the sequence of the $E g l C$ core region, TAIL-PCR was used to amplify the flanking sequences of the DNA fragment. Finally, a 1,107 bp fragment was obtained from $C$. farmeri A1 (Fig. 1). The open reading frame was predicted to encode a protein of 368 amino acids with a theoretical molecular mass of $39.1 \mathrm{kDa}$. Sequence analysis revealed a signal peptide with a length of 21 amino acids at the N-terminal of the enzyme. A BLAST search was used to predict the mature EglC of $C$. farmeri, revealing that the mature EglC belongs to glycoside hydrolase family 8 (Fig. 2). Additionally, the deduced EglC had 86.4\%, 43.4\%, 44.7\%, 39.7\%, and $44.3 \%$ amino acid sequence identity with endo- $\beta-1,4$-glucanases from E. coli CFT073, Burkholderia sp. CCGE1002, Cupriavidus taiwanensis, Pseudomonas fluorescens SBW25, and Xanthomonas campestris pv. vesicatoria strain 85-10, respectively (Fig. 3). The nucleotide sequence of $E g l C$ was deposited in the GenBank database (GenBank accession no. KT313000). 
180

181

182

183

184

185

186

187

188

189

190

191

192

193

194

195

196

197

198

199

200

201

202

\section{Expression and purification of EglC22b}

The mature EglC gene without the signal peptide was cloned into the pET22b vector for expression. SDS-PAGE revealed that the apparent molecular mass of EglC22b was approximately $42 \mathrm{kDa}$ (Fig. 4). This band was not present in non-transformed strains. The activity of the E. coli pET22b-EglC crude extract was $9.5 \mathrm{U} / \mathrm{ml}$.

The crude EglC22b was purified using $\mathrm{Ni}^{2+}$-NTA affinity chromatography, as a protein with the expected MW (42 kDa) was present in the SDS-PAGE gel (Fig. 4, lane 5). The specific activity of the purified enzyme was $8.7 \mathrm{U} / \mathrm{mg}$.

\section{Effects of pH and temperature on the activity of EglC22b}

The activity and stability of EglC22b were assayed in $\mathrm{CMC}-\mathrm{Na}$ at different $\mathrm{pH}$ values and temperatures. EglC22b showed optimal activity at $\mathrm{pH} 7.0$ and exhibited $>94 \%$ and $>85 \%$ relative activity at pH 6.5 and 8.0 (Fig. 5A). EglC22b was highly stable at $\mathrm{pH} 3.5-7.5$ and retained $>70$ $\%$ residual activity after $30 \mathrm{~min}$ of incubation in these buffers (Fig. 5B).

The recombinant enzyme had an optimal temperature of $30-40{ }^{\circ} \mathrm{C}$ and exhibited $>50 \%$ relative activity even at $5{ }^{\circ} \mathrm{C}$ (Fig. 6A). The activity of EglC22b was lost rapidly at temperatures higher than $60{ }^{\circ} \mathrm{C}$ (Fig. 6A). The thermotolerance analysis showed that approximately $90 \%$ of enzymatic activity was lost after $30 \mathrm{~min}$ of incubation at $60^{\circ} \mathrm{C}$ (Fig. 6B).

\section{Effects of chemical reagents and metal ions on the activity of EglC22b}

The effects of various chemical reagents and metal ions on the activity of EglC22b were tested (Fig. 7). The presence of $\mathrm{Cd}^{2+}, \mathrm{Zn}^{2+}, \mathrm{Li}^{+}$, Triton $\mathrm{X}-100$, DMSO, acetonitrile, Tween 80, EDTA, and SDS inhibited the activity of EglC22b. However, the presence of $\mathrm{Co}^{2+}$ and $\mathrm{Fe}^{3+}$ increased the activity of EglC22b.

\section{DISCUSSION}


203

204

205

206

207

208

209

210

211

212

213

214

215

216

217

218

219

220

221

222

223

224

225

Our previous study showed that $C$. farmeri A1 from the gastrointestinal tract of $R$. labralis is an effective cellulase-producing bacterium (carbon source: CMC-Na; unpublished). Although many endoglucanases from various microorganisms including fungus, bacteria, and actinomycetes have been studied, no endoglucanase from C. farmeri has been characterized to date (Shelomi et al., 2014; Asgher et al., 2013). In the present study, a cold-adapted endoglucanase was cloned from $C$. farmeri A1 and expressed in E. coli. The recombinant enzyme was purified to determine its biochemical properties.

The EglC gene was obtained from the DNA of $C$. farmeri A1 by TAIL-PCR. The deduced amino acid sequence of EglC is highly similar to the amino acid sequence of the EglC from $E$. coli CFT073. BLAST analysis suggested that EglC is a member of the GH 8 family. The amino acid sequence of EglC included a signal peptide (21 amino acids) and mature protein. For characterization, the mature protein of EglC was expressed in E. coli. SDS-PAGE revealed that the molecular weight (MW) of EglC22b was approximately $42 \mathrm{kDa}$, which was similar to the theoretical MW of $39.1 \mathrm{kDa}$.

EglC22b was characterized as a neutral enzyme (i.e., active at neutral $\mathrm{pH}$ ). The recombinant EglC22b was active at $\mathrm{pH}$ 6.5-8.0 with optimum activity at $\mathrm{pH} 7.0$, which was similar to the characteristics of $C$. farmeri EglC and the endoglucanase (Umce19B) isolated from compost soil microorganisms (Pang et al., 2009). The present results indicate that EglC22b was highly stable at $\mathrm{pH}$ 3.5-6.5 for $30 \mathrm{~min}$. Similar $\mathrm{pH}$ stability was also observed in the EG5C endoglucanase from Paenibacillus sp. IHB B 3084 (Dhar et al., 2015).

Although many endoglucanases have been studied, only few cold-adapted enzymes have been reported (Fu, et al., 2010; Ueda et al., 2014). It is known that cold-adapted enzymes show relatively high activity at low temperatures and have a low optimal temperature and poor thermal 
226 stability (Dhar et al., 2015). EglC22b showed optimal activity at $30-40{ }^{\circ} \mathrm{C}$ and more than $50 \%$

227 maximal activity at $10{ }^{\circ} \mathrm{C}$. It also had relatively poor thermal stability, where approximately $90 \%$

228 of its activity was lost after incubation at $60^{\circ} \mathrm{C}$ for $30 \mathrm{~min}$. These temperature properties suggest

229 that EglC22b has typical characteristics of cold-active endoglucanases, which was identical to

230 the EglC of $C$. farmeri A1. Similar results were also previously observed for endoglucanase and

231 cellulase from Paenibacillus sp. IHB B 3084 (a psychrophilic deep-sea bacterium) and Eisenia

232 fetida (Dhar et al., 2015; Yang et al., 2011; Zeng et al., 2006; Ueda et al., 2014). In contrast, the

233 mesophilic and thermmophilus endoglucanases were previously shown to rapidly lose activity at

234 temperatures below $20^{\circ} \mathrm{C}$ (Bischoff et al., 2007; Li et al., 2011).

235 Several reports have indicated that $\mathrm{Co}^{2+}$ can enhance the activity of endoglucanases from $E$. 236 coli Rosetta 2 and Aspergillus niger (Rawat et al., 2015; Martin et al., 2014). In the present study, 237 the activity of EglC22b was also increased by the presence of $\mathrm{Co}^{2+}$. Furthermore, SDS and 238 DMSO were found to almost totally inhibit the activity of EglC22b $(<10 \%)$, which was in 239 agreement with a previous study (Dhar et al., 2105; Manavalan et al., 2015).

\section{CONCLUSION}

241 An EglC gene was cloned from C. farmeri A1 and then expressed in E. coli. Biochemical 242 characteristics of EglC22b indicated that it was a low-temperature-active endoglucanase. Coldadapted endo-1,4- $\beta$-glucanases can protect thermolabile substrates, reduce energy consumption,

and minimize the rate of nonspecific chemical reactions. Further studies in our laboratory will

245 focus on its applications in the feed, food and silage industry.

246 ADDITIONAL INFORMATION AND DECLARATIONS

247 DNA Deposition

248 The following information was supplied regarding the deposition of DNA sequences: 
References

251

252

253

254

255

256

257

258

259

260

261

262

263

264

265

266

267

268

269

Asgher M, Ahmad Z, Iqbal HMN. 2013. Alkali and enzymatic delignification of sugarcane bagasse to expose cellulose polymers for saccharification and bio-ethanol production. Industrial Crops and Products 44:488-495 DOI 10.1016/j.indcrop.2012.10.005.

Bhat A, Riyaz-Ul-Hassan S, Ahmad N, Srivastava N, Johri S. 2013. Isolation of cold-active, acidic endocellulase from Ladakh soil by functional metagenomics. Extremophiles 17:229239 DOI 10.1007/s00792-012-0510-8.

Brune A. 2014. Symbiotic digestion of lignocellulose in termite guts. Nature Reviews Microbiology 12:168-180 DOI 10.1038/nrmicro3182.

Bischoff KM, Liu S, Hughes SR. 2007. Cloning and characterization of a recombinant family 5 endoglucanase from Bacillus licheniformis strain B-41361. Process Biochemistry 42:11501154 DOI 10.1016/j.procbio.2007.05.001.

Cavicchioli R, Charlton T, Ertan H, Omar SM, Siddiqui KS, Williams TJ. 2011. Biotechnological uses of enzymes from psychrophiles. Microbial Biotechnology 4:449-460 DOI 10.1111/j.1751-7915.2011.00258.x.

Dhar H, Kasana RC, Dutt S, Gulati A. 2015. Cloning and expression of low temperature active endoglucanase EG5C from Paenibacillus sp. IHB B 3084. International Journal of Biological Macromolecules 81:259-266 DOI 10.1016/j.ijbiomac.2015.07.060.

Fu X, Liu P, Lin L, Hong Y, Huang X, Meng X, Liu Z. 2010. A novel endoglucanase (Ce19P) from a marine bacterium Paenibacillus sp. BME-14. Applied Biochemistry and 
Biotechnology 160:1627-1636 DOI 10.1007/s12010-009-8648-2.

271

272

273

274

275

276

277

278

279

280

281

282

283

284

285

286

287

288

289

290

Gerday C, Aittaleb M, Bentahir M, Chessa JP, Claverie P, Collins T, D’Amico S. 2000. Coldadapted enzymes: from fundamentals to biotechnology. Trends in Biotechnology 18:103107 DOI 10.1016/S0167-7799(99)01413-4.

Kasana RC, Gulati A. 2011. Cellulases from psychrophilic microorganisms: a review. Journal of basic microbiology 51: 572-579 DOI 10.1002/jobm.201000385

Limayem A, Ricke SC. 2012. Lignocellulosic biomass for bioethanol production: current perspectives, potential issues and future prospects. Progress in Energy and Combustion Science 38:449-467 DOI 10.1016/j.pecs.2012.03.002.

Li J, Tang C, Shi H, Wu M. 2011. Cloning and optimized expression of a neutral endoglucanase gene (ncel5A) from Volvariella volvacea WX32 in Pichia pastoris. Journal of Bioscience and Bioengineering 111:537-540 DOI 10.1016/j.jbiosc.2011.01.002.

Maharana AK, Ray P. 2015. Optimization and characterization of cold-active endoglucanase produced by Aspergillus terreus strain AKM-F3 grown on sugarcane bagasse. Turkish Journal of Biology 39:175-185

Martin M, Biver S, Steels S, Barbeyron T, Jam M, Portetelle D, Michel G, Vandenbol M. 2014. Identification and characterization of a halotolerant, cold-active marine endo- $\beta$ - 1 , 4glucanase by using functional metagenomics of seaweed-associated microbiota. Applied and Environmental Microbiology 80:4958-4967 DOI 10.1128/AEM.01194-14.

Manavalan T, Manavalan A, Thangavelu KP, Heese K. 2015. Characterization of a novel endoglucanase from Ganoderma lucidum. Journal of Basic Microbiology 55:761-771 DOI 
10.1002/jobm.201400808.

292

293

294

295

296

297

298

299

300

301

302

303

304

305

306

307

308

309

310

311

Ozioko PC, Eze SOO, Chilaka FC. 2013. Partial purification and characterization of cellulases from digestive tracts of the African giant snail (Achatina achatina). Turkish Journal of Biology 37:199-205

Ogura J, Toyoda A, Kurosawa T, Chong AL, Chohnan S, Masaki T. 2006. Purification, characterization, and gene analysis of cellulase (Cel8A) from Lysobacter sp. IB-9374. Bioscience Biotechnology and Biochemistry 70:2420-2428 DOI 10.1271/bbb.60157.

Pang H, Zhang P, Duan CJ, Mo XC, Tang JL, Feng JX. 2009. Identification of cellulase genes from the metagenomes of compost soils and functional characterization of one novel endoglucanase. Current Microbiology 58:404-408

DOI 10.1007/s00284-008-9346-y.

Rawat R, Kumar S, Chadha BS, Kumar D, Oberoi HS. 2015. An acidothermophilic functionally active novel GH12 family endoglucanase from Aspergillus niger HO: purification, characterization and molecular interaction studies. Antonie van Leeuwenhoek 107:103-117 DOI 10.1007/s10482-014-0308-z.

Shelomi M, Jasper WC, Atallah J, Kimsey LS, Johnson BR. 2014. Differential expression of endogenous plant cell wall degrading enzyme genes in the stick insect (Phasmatodea) midgut. BMC Genomics 15:1 DOI 10.1186/1471-2164-15-917.

Tiwari R, Nain PKS, Singh S, Adak A, Saritha M, Rana S, Sharma A, Nain L. 2015. Cold active holocellulase cocktail from Aspergillus niger SH3: process optimization for production and biomass hydrolysis. Journal of the Taiwan Institute of Chemical Engineers 56: 57-66 DOI 
313 Ueda M, Ito A, Nakazawa M, Miyatake K, Sakaguchi M, Inouye K. 2014. Cloning and 314 expression of the cold-adapted endo-1, 4- $\beta$-glucanase gene from Eisenia fetida. 315 Carbohydrate Polymers 101:511-516 DOI 10.1016/j.carbpol.2013.09.057.

316 Vester J, Glaring MA, Stougaard P. 2014. Discovery of novel enzymes with industrial potential 317 from a cold and alkaline environment by a combination of functional metagenomics and 318 culturing. Microbial Cell Factories 13: 72 DOI 10.1186/1475-2859-13-72

319 Yasir M, Khan H, Azam SS, Telke A, Kim SW, Chung YR. 2013. Cloning and functional 320 characterization of endo- $\beta$-1, 4-glucanase gene from metagenomic library of vermicompost. Journal of Microbiology 51:329-335 DOI 10.1007/s12275-013-2697-5.

322

323

324
Yang J, Dang H. 2011. Cloning and characterization of a novel cold-active endoglucanase establishing a new subfamily of glycosyl hydrolase family 5 from a psychrophilic deep-sea bacterium. FEMS microbiology Letters 325:71-76 DOI j.1574-6968.2011.02413.x.

Zeng R, Xiong P, Wen J. 2006. Characterization and gene cloning of a cold-active cellulase from a deep-sea psychrotrophic bacterium Pseudoalteromonas sp. DY3. Extremophiles 10:79-82 DOI10.1007/s00792-005-0475-y. 


\section{Table $\mathbf{1}$ (on next page)}

Primers used in this study. 
1 Table 1 Primers used in this study.

\begin{tabular}{|c|c|}
\hline Primer name & Primer sequence $\left(5^{\prime} \rightarrow 3^{\prime}\right)$ \\
\hline GH8-F & GARGGNCARWSNTAYGCNATGTTYTTYGC \\
\hline GH8-R & CATNCCNGCCCANARRTANACNCKDAT \\
\hline FSP1 & TCTCTGGCTTCAGTTGCCAGCCTT \\
\hline FSP2 & AAGCGGGCGAAATACTGCGCCAGCT \\
\hline FSP3 & GCACCGTTACCACTTCTTCGCT \\
\hline $\mathrm{C} 1$ & GTNCGASWCANAWGTT \\
\hline RSP1 & TGGTTTTGCCGAAGCCAACGC \\
\hline RSP2 & TGCGCGAAACCAACCAGCGACT \\
\hline RSP3 & CCAGAGAAAACGCTGGTCAG \\
\hline $\mathrm{C} 2$ & NGTCGASWGANAWGAA \\
\hline GHF & ATGAACGCGTTGCGTAGTGG \\
\hline GHR & TTAATTTGAACTTGCGCATTCCT \\
\hline EglC-F & CTTCCATGGGCCTGTACCTGGCCCGCAT (NcoI) \\
\hline EglC-R & CCGCTCGAGATTTGAACTTGCGCATTCCTGG (XhoI) \\
\hline
\end{tabular}

2

3 


\section{Figure 1}

Amplification of a DNA fragment encoding the EgIC gene from Citrobacter farmeri A1.

Lane M: DNA marker (100-2,000 bp); lane 1: 1,107 bp PCR product. 
bp

2000

1000

750

500

250

100
$\mathbf{M}$

1

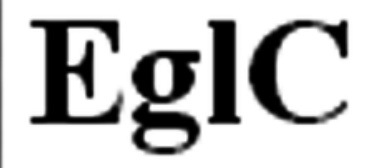




\section{Figure 2}

Conserved domains prediction of the EgIC.

Conserved domains prediction was performed by NCBI CD-search software

(https://www.ncbi.nlm.nih.gov/Structure/cdd/wrpsb.cgi).

Query seq.

Specific hits

Superfanilies

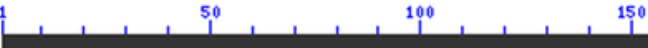

PRK11097

Glyco_hydro_8 superfamily 


\section{Figure 3}

Comparison of EglC protein sequences from different microorganisms.

A: Citrobacter farmeri A1 (This study); B: Escherichia coli CFT073 (GenBank accession no.

AAN82779); C: Pseudomonas fluorescens SBW25 (GenBank accession no.

WP_012721724.1); D: Xanthomonas campestris pv. vesicatoria str. 85-10 (GenBank accession no. WP_011348564.1); E: Burkholderia sp. CCGE1002 (GenBank accession no.

WP_012355143.1); F: Cupriavidus taiwanensis (GenBank accession no. WP_012355143.1). Multiple sequence alignment was performed by Clustal Omega software (http://www.ebi.ac.uk/Tools/msa/clustalo/). Asterisks show residues in the column are identical in all sequences in the alignment. Dots show semi-conserved substitutions observed in the alignment. Colons show conserved substitutions. 
C
A
B
F
D
E

A

B

F

D

E

C

A

B

F

D

E

C

A

B

F

D

E

C

A

B

F

D

E

C

A

B

F

E

C

A

B

F

D

E

C
B
F
D
E
MS--------PLKCMLAL-AALG---------AVMFVGSAQAQTCDWPLWQNYAKRFV --M---MKM-----N---------VLRSGLVT-------ML-LLAAFSVQAACTWPAWEQFKKDY I -----MITDQTRRRYVTYACALGASALTAAWPTETRAHAPPATRRASRWPLYRQFLERFV MSAHAHTGGMTRRRLLHAGALAGVAA-------LLPAAARAAPSQCGPWPLWSAFVDKHI MR-----FRIDRRTSFALALGIGIAASASLAASSGTAQAAQNGAACGDWSAWRTFVQRFV * : : : . .

39

36

38

54

53

55

96

93

95

111

110

115 QADGRVIDYSTPTQQTTSEGQSYALFFALVANDRATFDKLLGWTRANLAGDQFDAQNLRL

: :***:: $\quad:: * * * * * *$ : : ***. :*: ***:*:.: :

PGWLWGKKADNTWGVIDPNSASDADLWMAYALLEAARVWNAPQYRADAQLLLANVERNL I PAWLWGQKEPSTWAVLDSNSASDGDIWIAWSLLEAGRLWKEPRYTDIGKALLKRIASEEV PAWLWGKKENSKWEVLDSNSASDGDVWMAWSLLEAGRLWKEQRYTDIGSALLKRIAREEV PAWQWGRRADGTWGVLDR.YPAADADLWFAFALAEAARLWQAPSYADAARALLRRVAAQEV PAWLWGRDGGSAWRVLDANTASDGELWIAYALLEAGRLWSRPGYLKAGQQMLQL IRTQEV PAWQWGKKPDGSYGVLDPNSASDSDLWIAYDLLQAGRLWHSPAYTQLGQALAER IAHDEV *. ***: $\quad: *$ : $* * *: *$ : : :*:*: * :*.*:* $*$ : : : : :

VRVPGLGKULLPGPVGYVHAG----GLWRFNPSYQVLAQLRRFHKERPNAGWNEVADSNA VTVPGLGSMLLPGKIGFAEAN-----AWRFNPSYLPPQLAQYFARF--GAPWSTLRETNQ VTVPGLGSMLLPGKVGFAEDN-----SWRFNPSYLPPTLAQYFTRF--GAPWTTLRETNQ VTLPGFGPMLLPGPQGF IDDGPDGSRRWRLNASYLPVPLLRRLAAFDPSGPWDKLAAQVA ATLPGLGPMLLPGRTGFVDNG-----RWTLNPSYLPIQVLRRCANADPKGPWAAIAANSA ANLSGLGPMLLPGAQGFRNGG-----VTRLNPSYLPLPLLRALAHEVPDGPWAKLADNAY . : *:****** *:. $: * * * \quad:$. * :

KMLADTASNPHGLAANWVGYRATSANTGLFVVDPFSDDLGSYDAIRTYMWAGMTAKGDPL RLLLET--APKGFSPDWVRYEK----NKGWQLKPEKTLVSSYDA IRVYLWAGMMHDGDPQ RLLLET--APKGFSPDWVRYEK----DKGWQLKAEKTL ISSYDA IRVYMWVGMMPDSDPQ RL IGAV--SHAGIVPDWSAYRVGGR-RQGFVRDPVKGDVSSYDAVRVYLWAGMTPDQDST RVLRDS--APVGFAPDWTVWDG-----KTFNADPKRG.VVGSYDA IRVYLWAGMLDAGEPL QFVKTV--SPQGFAPDWAAWQN-----GRFVVDPKHGDVGSYDAIRVYLWAGLASPADPL :. : $\quad *: \quad: * \quad: \quad$ : . $\quad$ :.*****:*.*:*.*: :

AAPMLKSLGGMTRATAASATGYPPEKIHVLTGEVEKNTGYTPMGFSASTVAFFQARGETA KARLLAKFKPMATLT--TKNGLPPEKVDVASGKA---QG.NGPVGFSAALLPFLQNRDAQA KARMLNRFKPMATFT--EKNGYPPEKVDVATGKA---QGKGPVGFSAAMLPFLQNRDAQA WGAIMQALLPNAARL--AGRAAPPEKMYAESGKV---EGIGPPAFSAALLPFLQAAGSPA RARLLKDLSGPADLL--AAQQTPAEKIDTARGVG---TGALPVGFSAALLPYLSALGKPA AKPWLGALGGMRAKV--AQNGFPPEKVSSTTGAS---SGEGPLSYWGALAPYFKTLGDEH

$$
\text { ***: * * * . : . : : : : }
$$

LAQLQKAKVDDALAKALAPSAPDTAQPIYYDYMLSLFSQGFADQKYRFEQDGTVKLSWEA VQ-----RQR------VTD--HFPGSDAYYSYVLTLFGQGWDQHRYRFTVKGELLPDWGQ VQ-----RQR------VAD--NFPGSDAYYNYVLTLFGQGWDQHRFRFSTKGELLPDWGQ LATQMARAQK------IVGAPPGPGGPTYYDTVLGLFGLGFMEGRYRFSASGQLDR---LLKAQAQRVP------AATQ-PAAAALPYFERTLALFGQGWLENRYRFAADGRLLPAWRT GLGLARTRLA------ALDASVPGREPVYYDRVLGLFGTGF IDGRYRFDEAGSLVPAWRA

\begin{tabular}{ll} 
ACAVTR- & 398 \\
ECASSN- & 368 \\
ECANSH- & 370 \\
\hline----- & 393 \\
PACAATT & 393 \\
ACD---- & 395
\end{tabular}




\section{Figure 4}

SDS-PAG analysis of the recombinant EgIC22b stained with Coomassie blue.

Lane M: protein MW marker (18.9-94.4 kDa); Lane 1: IPTG-induced E. coli pET22b-EgIC; Lane 2: E. coli pET22b-EgIC; Lane 3: IPTG-induced E. coli pET22b; Lane 4: E. coli pET22b; Lane 5: purified EgIC22b.
kDa
M
1
2
3
4
5

\section{4 \\ 66.4}

41.5

33.7

24.4

18.9 
Figure 5

The $\mathrm{pH}$ properties of EgIC22b.

A: Effect of $\mathrm{pH}$ on the activity of EgIC22b; B: The pH stability of EgIC22b. The EglC22b activity which was detected at optimal $\mathrm{pH}$ and temperature was regarded as $100 \%$. All measurements of the present study were carried out in duplicate. Data were presented as means with standard deviation (SD).

A

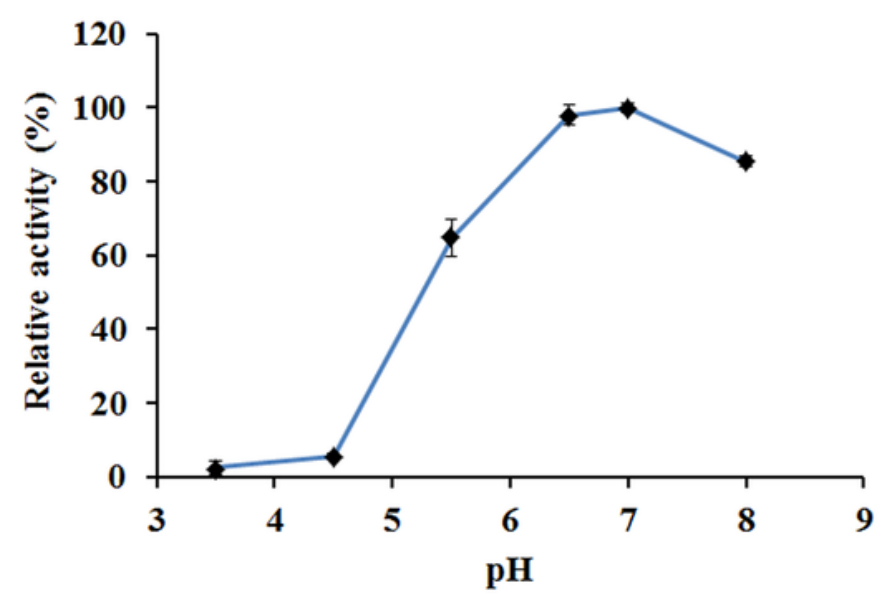

B

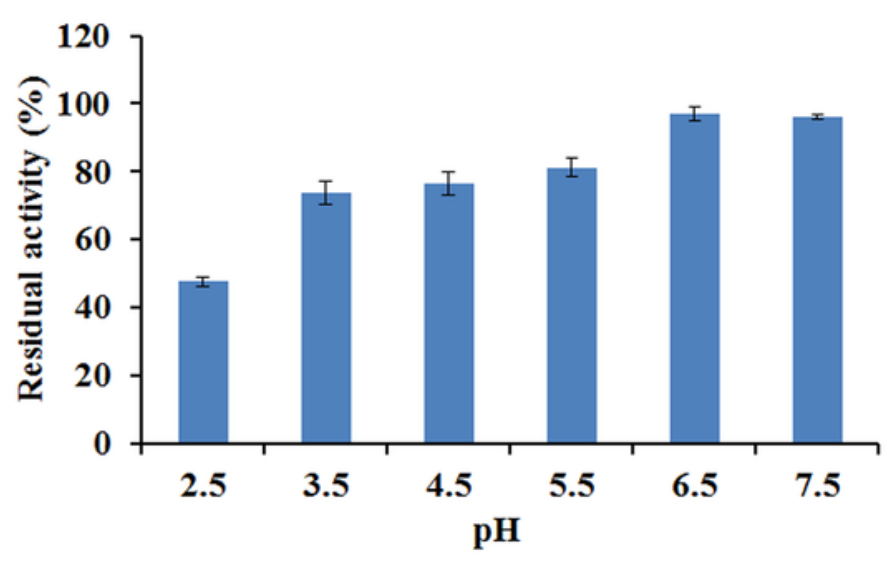


Figure 6

The temperature properties of EglC22b.

A: Effect of temperature on the activity of EgIC22b; B: The temperature stability of EgIC22b. The EgIC22b activity which was detected at optimal $\mathrm{pH}$ and temperature was regarded as $100 \%$. All measurements of the present study were carried out in duplicate. Data were presented as means with standard deviation (SD).

A

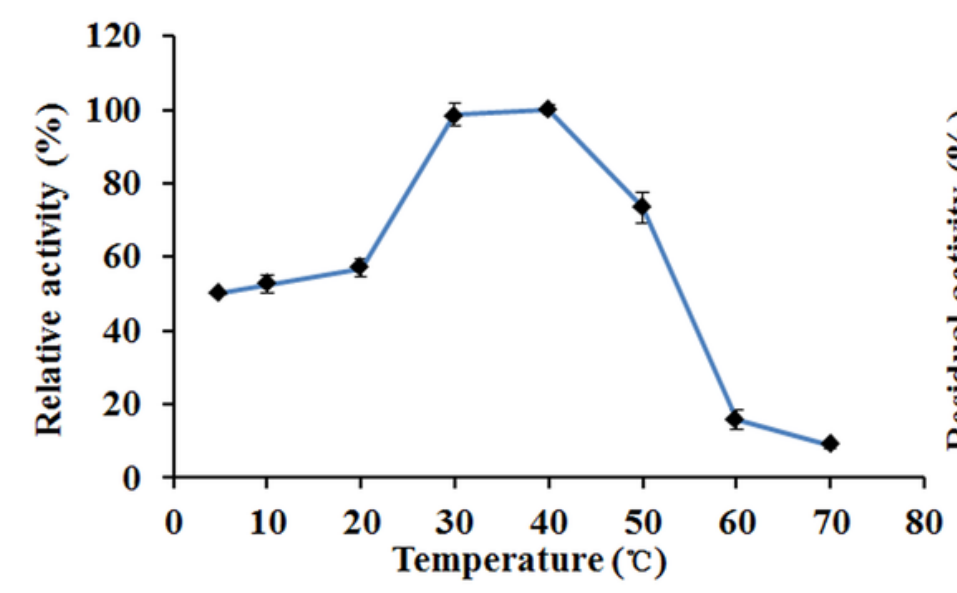

B

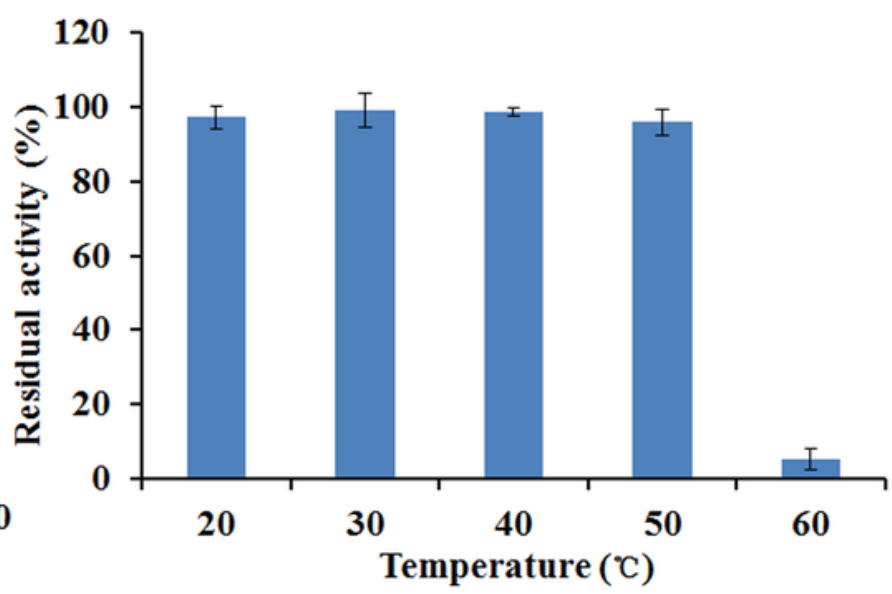


Figure 7

Effects of chemical reagents and metal ions on the activity of EgIC22b.

The EgIC22b activity which was detected at optimal $\mathrm{pH}$ and temperature was regarded as $100 \%$ (Control). All measurements of the present study were carried out in duplicate. Data were presented as means with standard deviation (SD).

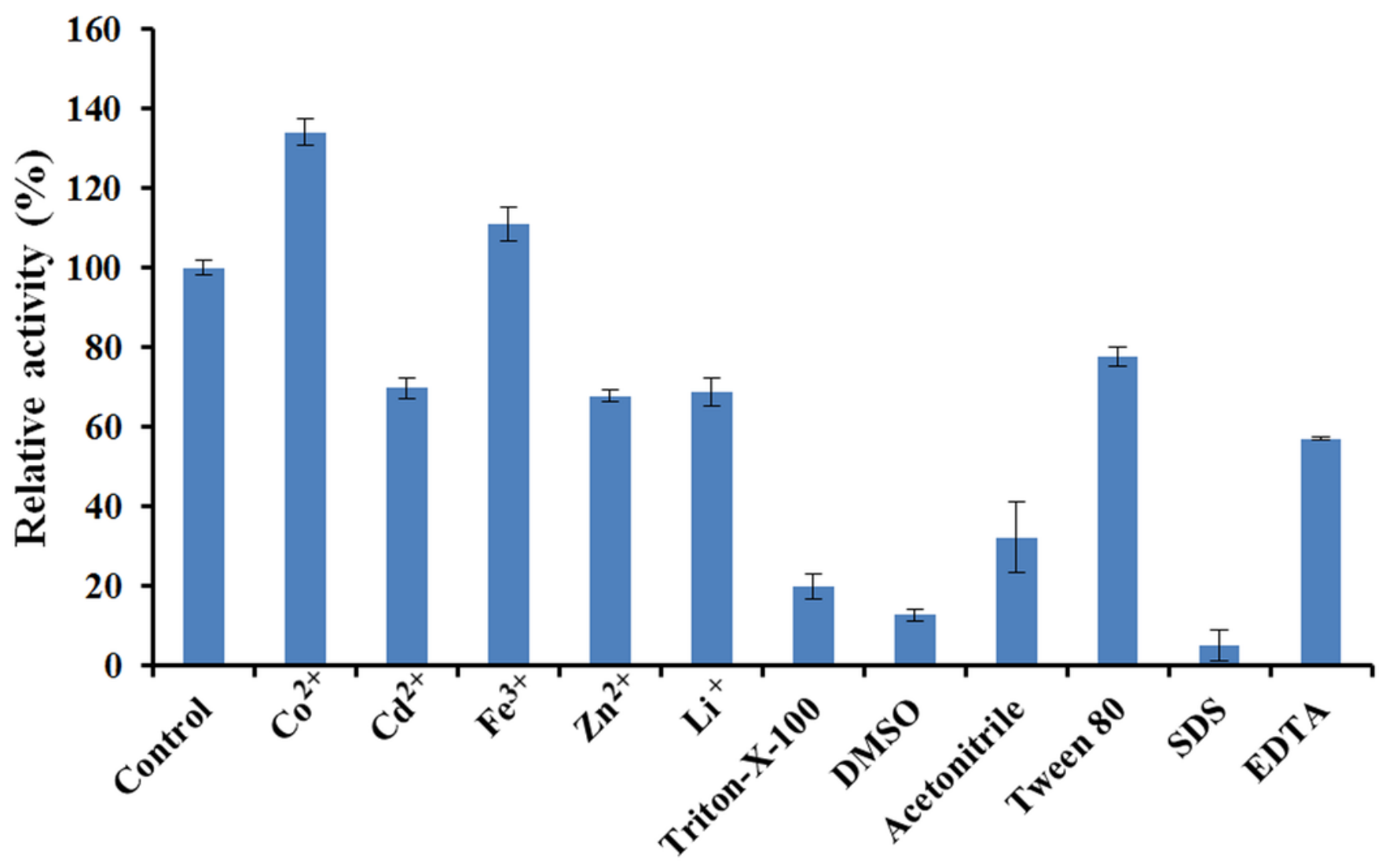

